United States) in 1989. Almost as a direct consequence, Turkish guest-workers will be displaced from West Germany in numbers comparable with those of the ethnic Turks being expelled from Bulgaria. In present circumstances, ethnic Hungarians in Romania would be heading for Hungary if their government would let them go, but the Soviet Union may end this year having lost 500,000 people, mostly to the United States and Israel. And then there are the boat people from Vietnam, not to mention those who escape from Cambodia while they can.

It is natural to regard these huge migrations as welcome signs of the liberalization of frontiers all over the world, but even voluntary migration is never trouble-free. People who complain of the trauma of moving house within a single country should multiply their impressions by some large number, say ten, to allow for the difficulties of settling into an entirely unfamilar environment. That is why the populations picking up their own roots to go elsewhere are naturally self-selected to include the most employable, which means those whose skills are technical and thus most portable.

There is worse to come. If Eastern Europe and the Soviet Union now keeps to the spirit of the Helsinki agreements, perestroika will have to be made to work to keep the skill it needs where it is needed. But even within the West, the growing conviction that the European Economic Community will yet become a true common market will mean that there are quite unpredictable movements of skilled people between member countries, which will further complicate the general drift of people to North America. What the British call the brain drain will become a general phenomenon.

How can the losers in this new labour market defend themselves? The only simple answer is that they will have to pay market prices in some sense or another. That does not necessarily mean that money salaries must everywhere become identical; working and living conditions are also important. Researchers and academics generally, but also people with skills in electronics and computer usage, are especially vulnerable in present circumstances. Wise employers, governments included, should begin planning now for the structural changes required to succeed in the coming competition for competence.

\section{Conduct unbecoming}

Runners-up to science prizes receive no recognition but should know better than to complain.

ONE of the stipulations in Alfred Nobel's will, finalized a year before his death in 1895 , was that the prizes to be awarded annually in his name should be awarded for discoveries made in the preceding year. Almost without exception, this stipulation is disregarded. But another, which limits to a maximum of three the number of people who may share a prize, is still honoured. Dominique Stéhelin, a French virologist, continues to argue (see page 329 ) that he should have been the third person named for this year's prize in physiology or medicine, awarded to Michael Bishop and Harold Varmus.

As all agree, Stéhelin was the main pair of hands behind the experiments that first showed that the oncogenes of tumour viruses are stolen and corrupted versions of genes from the cells that the viruses infect. So much is acknowledged by the fact that he is the first author on the 1976 Nature paper that reported this discovery and which the Nobel assembly cite as the seminal piece of work. Nevertheless, only the head of the laboratory in which Stéhelin was a visiting scientist and the head of an associated research team have been awarded the prize.

Is this rough justice? With the absolute rule that all Nobel decisions are final and without appeal, it will be 50 years before the reasoning of the Nobel committees can be examined. It seems likely, however, that two questions that will have been asked are these: would Stéhelin, had he been working in any other laboratory, have been an author on the seminal paper; and would the paper have emerged from the Bishop/Varmus milieu even had Stéhelin not been there? It is likely that the answers were no and yes, respectively, considerably diminishing Stéhelin's case.

Nonetheless, there is no rule to stop the Nobel authorities from including Stéhelin had they so wished. Precedent was clearly against it, with the exclusion of Jocelyn Bell from the 1974 physics prize although it was she who spotted the pulsar for which, in particular, Antony Hewish was awarded his half of the prize, as a notable example. On the other hand, Georges Köhler, the visiting scientist who worked on the discovery of monoclonal antibody technology in César Milstein's laboratory, shared the 1984 prize for physiology or medicine. It is, of course, up to those who award prizes to set the rules but in the case of the relative merits of dirty hands to fertile minds there seems not to be one.

Stéhelin's immediate reaction was ungentlemanly. His claims can surely not have been overlooked. There is no doubt that it is harder to achieve international visibility in Lille than in San Francisco, but Stéhelin, who shared with Sydney Brenner and Walter Gehring the valuable and esteemed 1987 Jeantet prize for European biomedical scientists, was certainly in view from Stockholm.

But how wise is his new outburst, which seems largely to have been occasioned by some remarks by a member of the committee that recommended the winners? If the press has accurately reported these remarks, Stéhelin has some cause for complaint, but his response will do him no good. Even so, his contributions should be generously acknowledged at the prize-giving ceremonies in Stockholm next month. That will also be a time for the Nobel authorities to reconsider the terms of the prizes. With teamwork now the rule rather than the exception in research, for how long can they continue to award their prizes on the basis that the winners take all, and the runners-up receive no recognition?

NATURE $\cdot$ VOL $342 \cdot 23$ NOVEMBER 1989 